\title{
MYCO- AND MICROORGANISMS IN THE TUBERCULOSIS PATHOLOGY OF THE COMMON ASH IN UKRAINE AND INTERACTION BETWEEN THEM
}

\author{
I. M. KULBANSKA, PhD in Biological Science \\ https://orcid.org/0000-0002-3424-8106, e-mail: i_kulbanska@ukr.net \\ A. F. GOYCHUK, Doctor of Agricultural Sciences, Professor \\ https://orcid.org/0000-0002-7770-9451, e-mail: ogoychuk@gmail.com \\ National University of Life and Environmental Sciences of Ukraine \\ M. V. SHVETS, PhD in Biological Science \\ https://orcid.org/0000-0002-1116-3986, e-mail: marina_lis@ukr.net \\ Polissia National University
}

\begin{abstract}
Attention is focused on the fact that in recent years there has been epiphytotic dieback out of many species of forest woody plants both in Ukraine and in other countries of the world, which has a dynamic character and a tendency to grow. In the deep pathology of this phenomenon, phytopathogenic bacteria, which have high reproduction energy and can penetrate the plant both from the outside and cause a pathological process as vital obligates, were left without attention.

It has been established that the most common and harmful disease of common ash in Ukraine is tuberculosis. The causative agent of the disease is the phytopathogenic bacterium Pseudomonas syringae pv. savastanoi Gard. affects both trunks, branches and shoots, and inflorescences of common ash. Bacteria Pseudomonas sp., Pseudomonas fluorescens Mig., Pseudomonas syringae Van., Erwinia herbicola Eh., Xanthomonas sp. were isolated from tuberculous pathology as a concomitant myco- and microbiota and micromycetes Cladosporium cladosporiodes Fres., Ulocladium botrytis Preus., Mycelia sterilia (dark), Mycelia sterilia (orange), Fusarium heterosporum Lin., Fusarium sp., W., Cylindrocarpon didymium Har., etc.

The mechanism of systemic relationships of the components of myco- and microbiota of tuberculous pathology of common ash in the regulation (self-regulation) of pathogenicity and aggressiveness of vital obligates has been investigated. Attention is focused on the prospects and expediency of using the antagonistic properties of myco- and microorganisms and biological products based on them for the prevention and protection of tree plantations from bacterial pathogens.

It is shown that the pathology of common ash is a multifaceted phenomenon with interrelated processes of an infectious and non-infectious nature. The need to distinguish between the etiology and pathogenesis of this negative phenomenon is indicated, that is, not to mix the factors that lead to the weakening of ordinary ash (factors catalyzing the disease) and the factors that cause its epiphytotic dieback.
\end{abstract} tanoi.

Keywords: bacteria, fungi, common ash, antagonism, Pseudomonas syringae pv. savas-

Introduction. Mico- and microorganisms are an integral part of the forest biocenosis, which determines its depth, which is directly involved in all stages of growth and development of woody plants and the utilization of mortmass and detritus. Among the systematic and functional groups of myco- and microbiota, a special place is occupied by phytopathogenic endophytes of various trophic specializations, capable of causing significant ecological, economic and social damage under certain conditions, which is confirmed by deep pathology 
with massive (epiphytotic) dieback out of many species of woody plants (Scots pine, spruce European, silver birch, common ash, in somewhat smaller volumes common oak, white fir, aspen, common hornbeam) both in Ukraine and abroad.

Analysis of recent researches and publications. In particular, the degradation and mass dieback out of tree plantations has reached a global level and has been noted practically throughout the entire range of many ash species, including common ash, both in European countries and in the USA and Asian countries (EPPO, 2020).

The pathology was first discovered in Northern and Central Europe in the 1990s (Kowalski \& Holdenrieder, 2009), and then was discovered in Germany and Sweden (Langer, 2017), Norway (Talgø, 2009), the Czech Republic, Slovakia and Finland (Jankovský \& Holdenrieder, 2009), Austria (Halmschlager \& Kirisits, 2008) and Hungary (Kirisits et al., 2009). In 2008, the disease spread to France (Husson, 2011), in 2009 it was Italy and Greece (Ogris, 2010), which caused the trees to dieback. The latest reports of noted pathology of Fraxinus excelsior L. were received from Belgium (Chandelier, 2009), Netherlands, England and Ireland (COST, 2011). In Ukraine, pathological dieback of ash has been reported since 2014 (Davydenko et al., 2013; Goychuk \& Kulbanska, 2014; Matsiakh \& Kramarets, 2014). Ash is currently dieback in 30 European countries (COST, 2011).

From different parts of the planet, there are reports of similar and different etiology and symptoms of tuberculous pathology. Based on scientific research, many possible pathogens - fungi have been put forward (Kowalski \& Holdenrieder, 2009; Lygis et al., 2005; Przybył, 2002; Langer, 2017) (in particular, $H y$ menoscyphus fraxineus Bar., which was identified in Ukraine (Davydenko et al.,
2013), bacteria (Cherpakov, 2012; Goychuk et al., 2019), nematodes (John, 1967; Ryss \& Polyanina, 2018), mycoplasmas (Bricker \& Stutz, 2004), representatives of harmful entomofauna (Korda et al., 2019), as well as the influence of climatic and soil-hydrological indicators (Goberville et al., 2016), however, no consensus has been reached yet.

Materials and methods of research. Material for the study of the peculiarities of tuberculous pathology of common ash was collected in fresh oak forests of Western Podillia of Ukraine, which, as you know, are optimal for the growth of highly productive deciduous forests with the participation of Fraxinus excelsior, in particular, in natural conditions on the territories of state forestry enterprises (Chortkivske forestry enterprise, Ternopilske forestry enterprise, Buchatske forestry enterprise). In the study area, Fraxinus excelsior usually grows in mixed stands with Acer pseudoplatanus L., Acer platanoides L., Quercus robur L., Tilia cordata Mill., Alnus glutinosa (L.) Gaerth., Prunus avium L., Carpinus avium L. and Ulmus campestris L., U. glabra Mill. However, there are also monocultures of ash, which are also characterized by high productivity. The vast majority of stands with Fraxinus excelsior have a stand density of $0.7-0.8$. The age groups are dominated by middle-age and pre-matured stands, which account for about $58 \%$ of the area of stands.

Affected samples were taken according to pathology of varying intensity, from trees of different age groups (young, by middle-age and matured stands) and from different parts of the trunk in transverse and longitudinal sections - from the bark, from the affected bast part, on the border of healthy and affected wood and visually healthy tissue.

During the research, reconnaissance and detailed methods of forest patho- 
logical examinations were used, as well as methods of phytopathological, microbiological and mycological studies according to generally accepted methods (Patyka, 2017), due to which studies of the pathogenic, anatomical-morphological, cultural and antagonistic properties of Pseudomonas syringae pv. savastanoi and associated bacteria and micromycetes in the tuberculous pathology of ash (Goychuk, 2020a).

In the laboratory of the D. K. Zabolotny Institute of Microbiology and Virology of the NASU homogenized and plated on potato agar (PA) pieces of affected tissues. Bacterial cultures were grown in a thermostat at a temperature of $26^{\circ} \mathrm{C}$. The number of microorganisms depending on functional and other traits was tested for their growth on special nutrient media (potato agar, meat-peptone agar, meat-peptone broth, malt extract of agar, a medium of Chapek, etc.). The pathogenic properties of the isolates were manifested in laboratory and field conditions by artificial infection of vegetative and generative organs of common ash and indicator plants (Phaseolus vulgaris L., Nicotiana tabacum L., Kalanchoe laciniata L.) with a bacterial suspension with a titer of 108-109 cells $\times \mathrm{ml}^{-1}$ (according to turbidity standard). Control sterile tap water. The placement and size of bacterial cells, Gram staining, the morphology of colonies of microorganisms, their biological, biochemical and cultural properties were studied using special methods (Patyka, 2017).

To determine the ability of bacterial isolates to ferment various sources of hydrocarbons, the mineral medium of Omelyansky was used. The following organic compounds were used as sources of carbohydrates: lactose, xylose, rhamnose, trehalose, raffinose, L-arabinose, maltose, sorbitol, salicin, sucrose, galactose, fructose, glycerin, mannitol, citrate.
The enzymatic or oxidative pathway of glucose uptake was determined by the growth of microorganisms on Omelyansky's medium under anaerobic conditions under a $1 \mathrm{~cm}$ layer of vaseline oil. The indicator was an aqueous solution of bromothymol blue. Milk and gelatin were used to detect proteolytic enzymes in bacteria. Interactions between microorganisms were investigated by the method of delayed antagonism. The test cultures were a standard set of bacterial strains from the collection of the Department of Phytopathogenic Bacteria of the D. K. Zabolotny Institute of Microbiology and Virology of the NASU, as well as isolated by us from vegetative and generative organs of common ash.

The antibacterial activity of biopesticides based on Bacillus sp. was investigated by titration and on ash in vivo.

To assess the typicality of the species of micromycetes and to determine their position in the structure of dominance in the biocenosis, we applied the criterion of a spacious frequency of occurrence. To study the typical diversity of fungi in the biogeocenosis, we used the concept of the seasonal frequency of occurrence of the species. To characterize the species composition of fungi in the wood samples under study, the Sorensen-Chekanovsky similarity coefficient was used.

Results of the research and their discussion. Nowadays, practically all systematic groups of myco- and microorganisms (as causative agents of diseases) are known on ordinary ash - fungi, bacteria, mycoplasma-like organisms (MPO), viruses, viroids, as well as algae, lichens, higher flowering plants, etc. Our research is aimed directly at establishing the species composition and mechanism of systemic relationships of the components of the myco- and microbiota of tuberculous pathology of common ash to regulate (self-regulate) the pathogenicity 


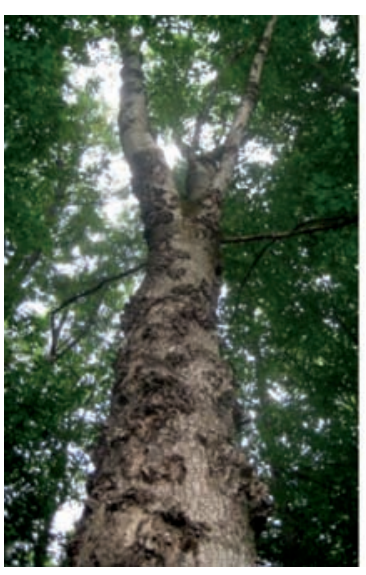

$a$

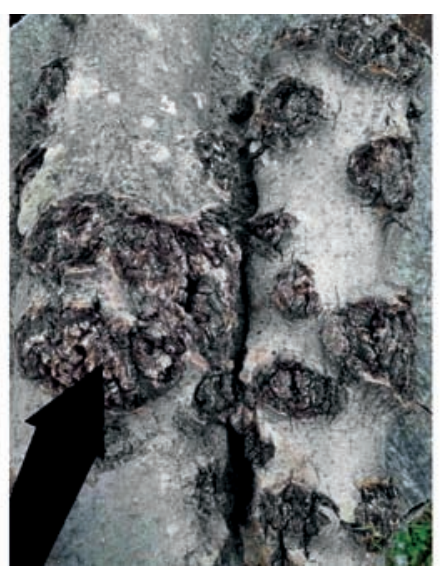

$b$

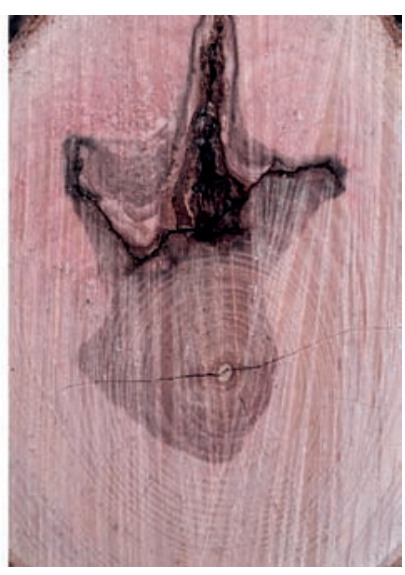

$c$

Fig. 1. Symptoms of tuberculous pathology of common ash: $a$ - general view of the affected Pseudomonas syringae pv. savastanoi tree; $b$ - tuberculous formations on the trunk; $c$ - the consequences of joint colonization of the ash trunk with the causative agent of tuberculosis, nectriosis and wood-coloring fungi

and aggressiveness of vital obligate as a permanent (inalienable, obligatory) presentation in a part of the plant organism.

The symptomatology of tuberculous pathology of common ash in the study region is typically infectious and manifests itself on the branches, trunks, and generative organs of ash. At the same time, instead of a smooth greenish-grey bark, small elliptical soft tumors are formed due to local swelling of the bark and filling the voids with an odorless gray sticky bacterial mass.

Over time, the affected areas of the trunk become flattered, crack, the cambium and bast in the middle part die off and collapse. In the center of tuberculous formations, a crack forms, which over time heals. However, complete overgrowth does not occur. From year to year, new tumors form, which spread both along the length and the perimeter of the trunk (branch). As a result, specific longterm lesions are formed, which outwardly resemble a "scab" (Fig. 1).

The number of wounds on a tree depends on the degree of injury and the age of the tree, but generally, on one affected tree, dozens and even hundreds of foci of tuberculosis can be counted. The presence of lesions deep in the trunk, which is overgrown with wood, usually spread along with the annual rings. Rotten areas on the trunk of an ash tree are formed exclusively during mixed infection with the formation of open ulcers with the participation of wood-destroying and wood-coloring fungi, in particular from the Ascomycota and Basidiomycota divisions. In the formation of open wounds (ulcers), usually the causative agents of common or stepped cancer, mainly Nectria galligena Bres., are involved or Endoxylina stellulata Rom. (anamorph - Libertella fraxini Ogan.). And then the disease proceeds with symptoms characteristic of these pathogens (stepped open ulcers are formed).

To establish the etiology of this phenomenon, we conducted special mycoand microbiological analyzes, the result of which is the identification of the pathogen and the species composition of 


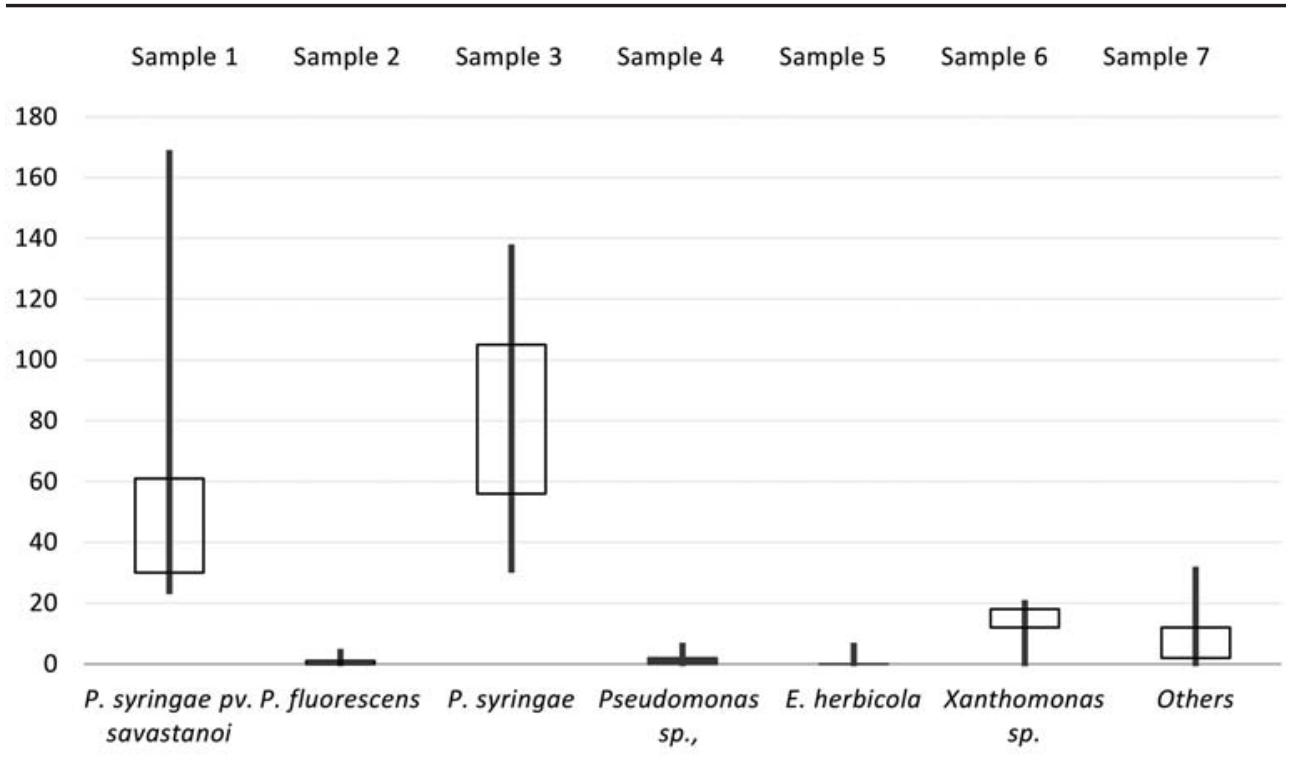

Fig. 2. Number of colony-forming units (CFU) bacteria isolated from vegetative and generative organs Fraxinus excelsior

concomitant myco- and microbiota of tuberculosis pathology.

As a result of determining the species composition of the pathogenic microflora of tuberculous pathology of common ash, 7 species of bacteria were identified. The analysis of the obtained results showed the similarity of the studied samples with the following species: Pseudomonas syringae pv. savastanoi, $P$. fluorescens, $P$. syringae, Pseudomonas sp., Erwinia. herbicola, Xanthomonas sp, Bacillus subtilis Eh. and Bacillus pumilus Eh. According to the results of artificial infection, the isolates showed pathogenicity both on ash-key, young ash trunks (branches), and on indicator plants. At the same time, they were non-pathogenic to the leaves of common ash (only minor damage to the leaf blade remained at the sites of the introduction of the bacterial inoculum).

The average values of bacteria isolated from the vegetative and generative organs of Fraxinus excelsior ranged from 1 to $168 \mathrm{CFU}$ (Fig. 2). The largest num- ber (116, $168 \mathrm{CFU})$ of bacteria was obtained by isolating Pseudomonas syringae pv. savastanoi.

Also, thanks to the results of artificial infection of common ash by injection into the trunks of a suspension of a daily culture of microorganisms (8.69.97 $\mathrm{CFU} \times \mathrm{ml}^{-1}$ ) and by introducing a pure bacterial culture under the bark (14.1-21.27 $\mathrm{CFU} \times \mathrm{ml}^{-1}$ ) (both in vivo and in vitro), we confirmed the bacterial etiology of tuberculous pathology (Fig. 3) and isolated the pathogen - the phytopathogenic bacterium Pseudomonas syringae pv. savastanoi. When carrying out the above-mentioned works, circadian rhythms of plant resistance (Gvozdyak, 2005 ) to bacteriosis pathogens were taken into account.

The agent isolated by us has typical features for the genus Pseudomonas. These are non-spore-bearing mobile rods $0.4-0.8 \times 1.3-3.0$ microns in size, gramnegative, placed singly, in pairs or in short chains, sometimes in groups, lophotrichs, with 1-6 polar flagella. The 

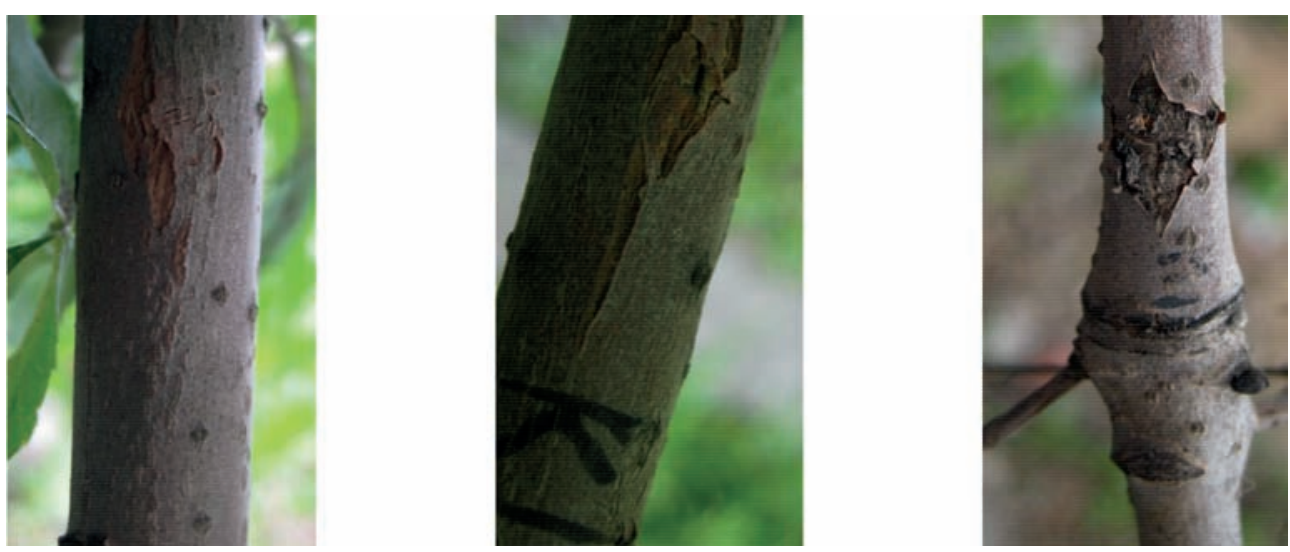

Fig 3. The result of artificial infection of the organs of common ash Pseudomonas syringae pv. savastanoi

ends of the sticks are smoothly rounded. On the potato agar, colonies are greywhite, smooth, round, transparent, with a denser center, with an equal or slightly wavy, sometimes with a blue tint, edge. Colonies on meat-peptone agar are small, 2-3 $\mathrm{mm}$ in diameter, grow slowly, graywhite, round, flat, or convex, with a notch in the center, transparent, with an equal or wavy edge. On meat-peptone broth, the growth is moderate, bacteria form uniform cloudiness. No growth was found on the Czapek and Omelyansky medium.

The strains are not homogeneous according to physiological characteristics. The aerobic, not fermenting glucose under vaseline oil. Bacteria assimilate sucrose, galactose, fructose, glycerin, mannitol, citrate; do not assimilate lactose, xylose, rhamnose, trehalose, raffinose, L-arabinose, maltose, sorbitol, salicin. They do not reduce nitrates. They cause a hypersensitivity reaction on the leaves of Nicotiana tabacum and form a fluorescent pigment on the potato agar.

Growth was noted at $37^{\circ} \mathrm{C}$. According to the given signs, the causative agent of tuberculous pathology is close to that described in the literature (Iacobellis \& Caponero, 1998; Cherpakov; 2012; Ramos et al., 2012; Suresh \& Rupert, 2016;
Caballo-Ponce et al., 2017; Goychuk et al., 2019).

In particular, growth (no growth) on most nutrient media, significant variability with food sources, relationship in the production of enzymes. The main differences are the absence of fluorescence in liquid nutrient media and the slow absorption of carbohydrates and alcohols. The heterogeneity and plasticity of this species are associated with the possibility of expanding the spectrum of nutritious plants.

In the course of our analysis of mycobiota, affected by tuberculous pathology of ash branches in the region, of the study in total (including identified only to the level of the genus Fusarium sp. and Phoma sp.). Were identified 7 genera and 10 species of micromycetes. Usually, the affected tissue samples had a mixed infection (Fig. 4).

The analysis of the obtained results showed the similarity of the studied samples with the following species: Acremonium strictum, Cladosporium cladosporiodes, C. didymum, Fusarium sporotrichiella Bilaivar. (Peck) Wol., Fusarium heterosporum, Fusarium sp., Mycelia sterilia (dark), M. sterilia (orange), Phoma sp., Ulocladium botrytis. 


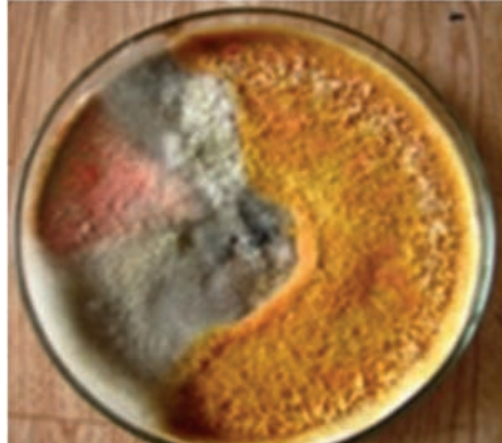

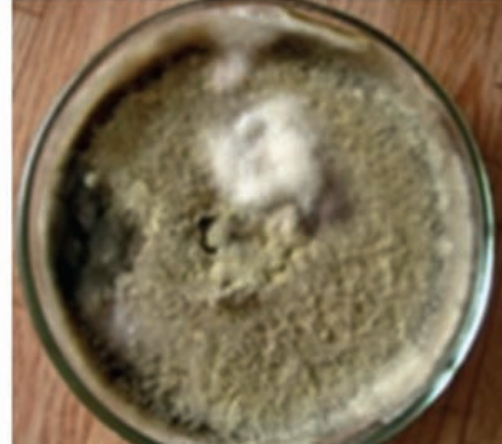

$b$

Fig. 4. Colonies of micromycetes isolated from vegetative and generative organs of affected trees Fraxinus excelsior: a-Mycelia sterilia (orange), M. sterilia (dark), Cladosporium cladosporiodes, Ulocladium botrytis; $b-U$. botrytis, Phoma sp., C. cladosporiodes

Based on the results obtained, it is possible to differentiate the identified species into separate categories, in particular, to assert that Ulocladium botrytis is a typical dominant species (spatial and seasonal frequency of occurrence exceeds $60 \%$ ). Typical numerous species include - Phoma sp., Cladosporium cladosporiodes, Mycelia sterilia (orange). Following the types of rare species - Acremonium strictum, Cladosporium didymum, Fusarium sporotrichiella, $F$. heterosporum, Fusarium sp. and M. sterilia (dark). There are no random species. Ulocladium botrytis is characterized by a high occupancy rate $(57.1 \%)$, while Acremonium strictum, $C$. didymum, and Fusarium sporotrichiella are characterized by a low one (14.3\%). F. heterosporum (Fig. 5).

Based on the calculation of the Sorensen-Chekanovsky similarity coefficient $(\mathrm{S}>0.5)$, we see that there are significant differences between the species composition of the compared stages of the study. In general, the results of the study showed that the mycobiota of infected branches of common ash is characterized by the presence of a complex of pathogenic species, dispersedly local- ized over the affected area. The results obtained confirm the assumption of the presence of a complex biological complex, dieback of tree stands. We also found a disease known as "ash dieback" ("deadly disease" of ash, "peripheral dying off", "pathogenic dieback of ash") in the studied stands). It should be noted that the symptoms have fundamental differences in comparison with tuberculosis. In affected plants, there is a rapid gradual (sometimes sudden) crown death due to the formation of local necrotic areas on the shoot (trunk). The leaves above the lesion site wither (starting from the top), and by the end of summer they turn black (like those burnt by fire) and do not fall off for a long time.

Studies have shown that the micromycete Chalara fraxinea Kow. is the causative agent of ash dieback (Kowalski, 2006; Davydenko et al., 2013; Matsiakh \& Kramarets, 2014). At the same time, attention was focused on the fact that $C$. fraxinea is an anamorph of Hymenosyphus pseudoalbidus (Kowalski \& Holdenrieder, 2009). We have isolated several species of anamorphic fungi from the pathology of the ash dieback type (we failed to isolate $C$. fraxinea) and bacteria, 


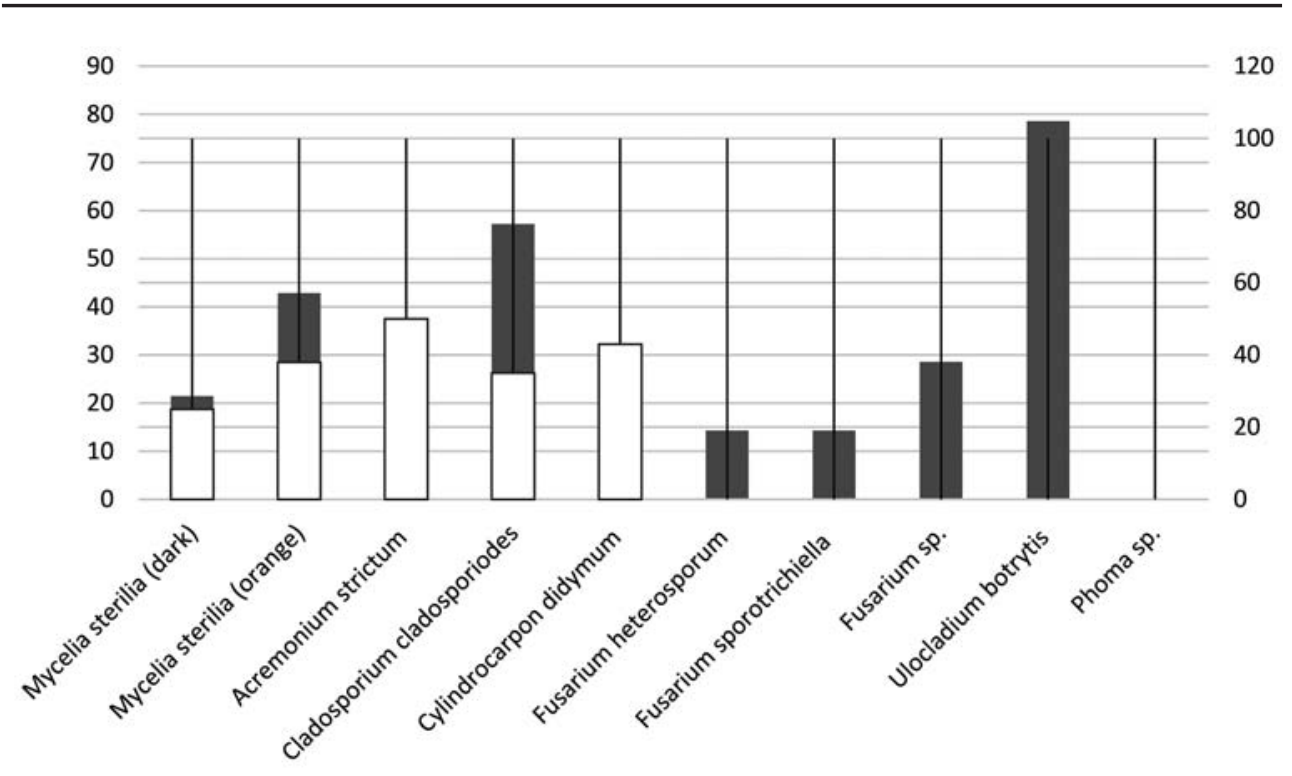

Fig. 5. Spatial and seasonal frequency of occurrence of micromycetes of tuberculous pathology of common ash

in particular Pseudomonas syringae pv. savastanoi, Erwinia horticola and Xanthomonas sp. Artificial infection of ash organs with micromycetes did not lead to symptoms similar to "ash dieback", and bacterial infections caused pathological processes similar to ash tuberculosis.

To initiate processes related to the activity of natural populations of hyperparasites, which are ecologically and trophically combined with bacterial phytopathogens, we investigated the relationship, in particular antagonistic, in the systems of "phytopathogenic bacteriahyperparasites" of tuberculous pathology of common ash.

The study of systemic relationships, primarily antagonistic, between different types of myco- and microorganisms, including saprotrophs and pathogens, pathogens of infectious plant diseases, including bacteriosis, in the context of identifying active antagonists to pathogenic components of myco- and micro- biota is extremely important and relevant. To study the antagonistic relationships in the system "bacterium-bacterium" and "bacterium-micromycete" in the laboratory, we used both isolated by us and collection strains of bacteria Pseudomonas syringae 8511, Pseudomonas savastanoi 9174, as well as micromycetes Ulocladium botrytis, Phoma sp., Cladosporium cladosporiodes, Acremonium strictum, Cladosporium didymum, Fusarium sporotrichiella, F. heterosporum, F. sp.

All strains were used in cross-reactions "basic culture-test culture". A total of 108 variants of reactions were delivered. During the research, we did not find antagonistic relationships between test cultures - pathogens of Fraxinus excelsior in the system "bacterium-bacterium". In contrast to bacteria, micromycetes isolated from the vegetative and generative organs of Fraxinus excelsior showed some antagonistic activity against phytopathogenic bacteria. The most active 
were Ulocladium botrytis and Cladosporium cladosporiodes with mean sterile zones of 5.8 and $4.9 \mathrm{~mm}$, respectively. They suppressed to varying degrees all test cultures of phytopathogenic bacteria. The activity of the other three micromycete species, Acremonium strictum, Fusarium heterosporum, and F. sporotrichiella, was selective. They did not inhibit the growth of Pseudomonas sp. ("Kr4") and Pseudomonas syringae pv. savastanoi ("Kr4") and weakly inhibited Pseudomonas syringae pv. savastanoi ("H1") and the collection Pseudomonas savastanoi 9174 . Other species of micromycetes did not show antibacterial activity. Bacteria Pseudomonas syringae pv. savastanoi (H1), Pseudomonas syringae 8511, Pseudomonas savastanoi 9174 were the most sensitive to all types of micromycetes.

Regarding the reverse effect, phytopathogenic bacteria on micromycetes, in most cases their antifungal activity was zero. Minor areas formed by the action of bacteria on micromycetes are also virtually zero. Such a result was obtained in the laboratory on an artificial nutrient medium, which differently affects the growth and activity of bacteria and micromycetes. In particular, bacteria grow intensively on the potato agar, and the growth of micromycetes is inhibited. At the same time, bacteria do not grow on Czapek medium due to the presence in these media of different nutrients for micromycetes and bacteria. Under natural conditions, the interaction in the systems "bacterium-bacterium", "bacterium-micromycete", "micromycete-bacterium" can and obviously should be different, because the micro- and microorganisms are influenced by various factors (woody plant at certain stages growth and development, its physiological state, the presence of a pathology, meteorological (synoptic) factors, including as catalysts of pathology, compliance of forest woody plant with forest conditions, etc.). However, experiments with coniferous forest woody plants have shown that phytopathogenic bacteria (so-called vital obligates) in natural conditions outside the pathological process do not affect the growth of micromycetes (Gvozdyak, 2005; Goychuk, 2020b). Studies of biological products ("Victant" and "P27ant") based on aerobic spore-forming bacteria Bacillus sp. no high antimicrobial activity was revealed for all studied cultures of microorganisms, and their activity depended not only on the type of bacteria but also on which organs of the ash tree it was isolated from (Fig. 6).

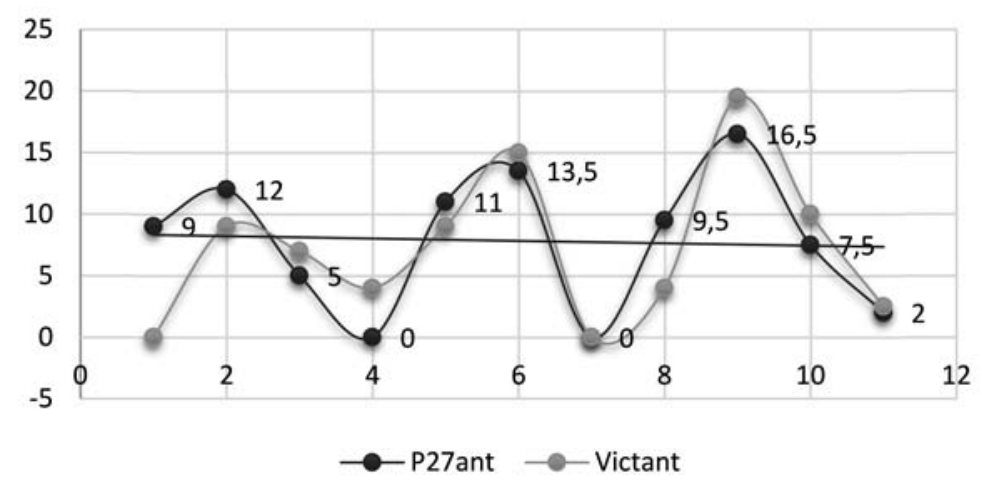

Fig. 6. Antimicrobial activity of "Victant" and the strain "P27ant" 
It was found that bacteria of the genus Bacillus sp. can suppress the adhesion and survival of phytopathogenic $P$. syringae pv. savastanoi on the surfaces and tissues of test plants, eliminating the pathogen population or decreasing its density with a possible attenuation of properties, the mechanism of which requires further research. Thus, our studies in combination with the results of other scientists indicate the presence of diseased trees Fraxinus excelsior complex biocomplex of pathogenic species, which directly involved in the dieback of ash stands. And, we found elements of antagonistic relationships between components of different systematic and functional groups of myco- and microorganisms indicate the possibility and necessity of using this phenomenon in the context of positive and negative feedback mechanisms to develop methods of biological protection of forest woody plants, including Fraxinus excelsior, from pathogens of infectious diseases, including bacteriosis.

Conclusions and future perspectives. Currently, the deterioration of phytosanitary conditions of plantations with the participation of Fraxinus excelsior is associated with various biotic (harmful entomofauna), biotic parasitic (micromycetes, bacteria, nematodes, mycoplasma factors, as well as adverse climatic (synoptic, synoptic, and many), including "ash dieback" and tuberculosis, which indicates the need for comprehensive studies of pathologies of forest woody plants, including epiphytic, in particular, diseases of forest woody plants are currently associated with exogenous infection.
Isolated by us the causative agent of tuberculous pathology of common ash Pseudomonas syringae pv. savastanoi on the following grounds is close to that described in the literature: growth (no growth) on most nutrient media, significant variability in relation to nutrient sources, and so on.

Erwinia horticola, Pseudomonas sp., P. fluorescens, P. syringae, P. aglomerans, Xanthomonas sp., spore-bearing bacteria Bacillius sp., as well as micromycetes Acremonium strictum, Cladosporium didymum, Fusarium sp., Fusarium sporotrichiella, F. heterosporum, Phoma sp., Ulocladium botrytis and the like isolated at different stages of tuberculous pathology of Fraxinus excelsior. Affected plants at any age have hidden faults in the wood (blackening, cracks, rotten areas with a significant spread along the trunk), which devalues it.

It was found that both isolated phytopathogenic bacteria and concerning test cultures of bacteria did not reveal antagonistic activity. In contrast to bacteria, micromycetes isolated from the vegetative and generative organs of common ash are characterized by a large antagonistic activity concerning phytopathogenic bacteria. Thus, we found, like other researchers, elements of antagonistic relationships between components of different systematic and functional groups of myco- and microorganisms indicate the possibility and necessity of using this phenomenon in the context of positive and negative feedback mechanisms for the development of means and methods of biological protection forest woody plants, including Fraxinus excelsior, from pathogens of infectious diseases, including bacteriosis.

\section{References}

Bricker, J. S., \& Stutz, J. C. (2004). Phytoplasmas associated with ash decline. J. Arboric, 30, 193-199.
Caballo Ponce, E., Murillo Martínez, J., Martínez Gil, M., Moreno Pérez, A., Pintado, A., \& Ramos, C. (2017). Knots untie: Molecular 
determinants involved in knot formation Induced by Pseudomonas savastanoi in woody hosts. https://doi.org/10.3389/ fpls.2017.01089

Chandelier, A., Delhaye, N., \& Helson, M. (2009). First report of the ash dieback pathogen Hymenoscyphus pseudoalbidus (anamorph: Chalara fraxinea) on Fraxinus excelsior in Belgium. Plant Disease, 95, 220-226.

Cherpakov, V. V. (2012). Bacterial diseases of forest species in pathology of forest. Journal SPb GLTU, 292-303 [in Russian].

COST 2011: European cooperation in science and technology. Fraxinus dieback in Europe: elaborating guidelines and strategies for sustainable management (FRAXBACK). Available at http://www.cost.eu/COST_Actions/fps/FP1103.

Davydenko, K., Vasaitis, R., Stenlid, J., \& Menkis, A. (2013). Fungi in foliage and shoots of Fraxinus excelsior in eastern Ukraine: a first report on Hymenoscyphus pseudoalbidus. Forest Pathology, 43 (6), 462-467. https:// doi.org/10.1111/efp.12055

EPPO. 2020. EPPO Global database. In EPPO Global database. Paris, France: EPPO. Available at https://gd.eppo.int/.

Goberville, E., Hautekèete, N.-C., Kirby, R., Piquot, Y., Luczak, C., \& Beaugrand, G. (2016). Climate change and the ash dieback crisis. Scientific Reports, 6, 35303. https:// doi.org/10.1038/srep35303

Goychuk, A., \& Kulbanska, I. (2014). Etiology of Common Ash Diseases in Podolia, Ukraine. Scientific Journal of NUBiP of Ukraine, 24.11, 15-19 [in Ukrainian].

Goychuk, A., Drozda, V., Kulbanska, I., \& Shvets, M. (2019). Phytopathogenic bacteria in the pathology of forest trees of polyssya and forest-steppe of Ukraine. Ukrainian Black Sea region agrarian science, 2, 2833. https://doi.org/ 10.31521/2313092X/2019-2(102)-4

Goychuk, A. F., Kulbanska, I. M., \& Shvets, M. V. (2020a). Associated with bacteria in pathology Fraxinus excelsior L. Microbiological Journal, 82 (3), 22-34. https://doi. org/10.15407/microbiolj82.03.022

Goychuk, A. F., Drozda, V. F., Shvets, M. V., \& Kulbanska, I. M. (2020b). Bacterial wetwood of silver birch (Betula pendula roth): symptomology, etiology and pathogenesis. Folia Forestalia Polonica, 62 (3), 145-159. https://doi.org/10.2478/ffp-2020-0015

Gvozdyak, R. I. (2005). Perspective directions of research of phytopathogenic bacteria. In Proceedings of the International Scientific Conference "Phytopathogenic bacteria. Phytoncidology. Allelopathy" (pp. 3-8). Zhytomyr [in Ukrainian].

Halmschlager, E., \& Kirisits, T. (2008). First report of the ash dieback pathogen Chalara fraxinea on Fraxinus excelsior in Austria. Plant Pathology, 57, 1177.

Husson, C., Scala, B., Caël, O., Frey, P., Feau, N., loos, R., \& Marcais, B. (2011). Chalara fraxinea is an invasive pathogen in France. European Journal of Plant Pathology, 130, 311-324. https://doi.org/10.1007/ s10658-011-9755-9

lacobellis, N. S., \& Caponero, A. (1998). Evidente Characterization of Pseudomonas syringae ssp. savastanoi strains isolated from ash. Plant Pathology, 47, 73-83. https://doi. org/10.1046/j.1365-3059.1998.00202.x

Jankovský, L., \& Holdenrieder, O. (2009). Ash and ash dieback in the Czech Republic. Plant Protection Science, 45, 74-78. https://doi.org/10.17221/45/2008-PPS

John, L. (1967). Ruehle Distribution of Plantparasitic Nematodes Associated with Forest Trees of the World. Plant Nematologist Forestry Sciences Laboratory Athens, Georgia. https://doi.org/10.5962/bhl.title.149734

Kirisits, T., Matlakova, M., Mottinger-Kroupa, S., Halmschlager, E., \& Lakatos, F. (2009). Chalara fraxinea associated with dieback of narrow-leafed ash (Fraxinus angustifolia). New Disease Reports, 1-2.

Korda, M., Csóka, Gy., Szabó, Á., \& Ripka, G. (2019). First occurrence and description of Aceria fraxiniflora (Felt, 1906) Acariformes: Eriophyoidea) from Europe, Zootaxa, 4568(2), zootaxa.4568.2.5. https://doi.org/ 10.11646/zootaxa.4568.2.5

Kowalski, T., \& Holdenrieder, O. (2009). The teleomorph of Chalara fraxinea, the causal agent of ash dieback. Forest Pathology, 39, 304-308. Available at http://www.blackwellsynergy.com/loi/efp. https://doi.org/10.1111/ j.1439-0329.2008.00589.x

Kowalski, T. (2006). Chalara fraxinea sp. nov. associated with dieback of ash (Fraxinus excelsior) in Poland. Forest Pathology, 36, 264-270.

Langer, G. (2017). Collar rots in forests of Northwest Germany affected by ash dieback. Baltic Forestry, 23, 4-19.

Lygis, V., Rimvydas, V., Karl-Henrik, L., \& Jan, S. (2005) Wood-inhabiting fungi in stems of Fraxinus excelsior in declining ash stands of northern Lithuania, with particular reference to Armillaria cepistipes. Scandinavian Journal of Forest Research, 20 (4), 337-346. https://doi.org/10.1080/02827580510036238

Matsiakh, I. P., \& Kramarets, V. O. (2014). Declining of Common Ash (Fraxinus excelsior L.) in Western Ukraine. Scientific Herald of National Forest Technical University of Ukraine, 24.7, 67-74 [in Ukrainian].

Ogris, N., Hauptman, T., Jurc, D., Floreancig, V., Marsich, F., \& Montecchio, L. (2010). First Report of Chalara fraxinea on Common Ash in Italy. Plant Disease - PLANT DIS, 94, 133-133. https://doi.org/10.1094/PDIS-94$1-0133 A$ 
Patyka, V. P., Pasichnyk, L. A., Gvozdyak, R. I., Petrichenko, V. F., et al. (2017). Phytopathogenic bacteria. Methods of research. Vinnytsia: Windruck [in Ukrainian].

Przybył, K. (2002). Fungi associated with necrotic apical parts of Fraxinus excelsior shoots Forest Pathology, 46 (4), 387-394. https://doi.org/10.1046/j.1439-0329. 2002.00301.x

Ramos, C., Matas, I. M., Bardaji, L., Aragón, I. M., \& Murillo, J. (2012). Pseudomonas savastanoi pv. savastanoi: Some like it knot. Molecular Plant Pathology, 13 (9), 998-1009. https://doi.org/10.1111/j. 1364-3703.2012.00816.x
Ryss, A., \& Polyanina, K. (2018). Characterization of Juvenile Stages of Bursaphelenchus crenati Rühm, 1956 (Nematoda: Aphelenchoidoidea). Journal of nematology, 50 , 459-472. https://doi.org/10.21307/jofnem-2018-042

Suresh, G. B., \& Rupert, A. Y. (2016). Bacterial Diseases of Forest Trees, Bacterial Diseases of Crop Plants. CRC Press. https://doi. org/10.1201/9781315367972

Talgø, V., Sletten, A., Brurberg, M. B., Solheim, H., \& Stensvand, A. (2009). Chalara fraxinea Isolated from Diseased Ash in Norway. Plant Disease, 93 (5), 548. https://doi. org/10.1094/PDIS-93-5-0548A

\title{
Кульбанська І. М., Гойчук А. Ф., Швець М. В. \\ МІКО- І МІКРООРГАНІЗМИ ТУБЕРКУЛЬОЗНОЇ ПАТОЛОГІЇ ЯСЕНА ЗВИЧАЙНОГО В УКРАЇНІ ТА ВЗАєМОВІДНОСИНИ МІЖ НИМИ
}

\begin{abstract}
Останніми роками спостерігається епіфітотійне всихання багатьох видів лісових деревних рослин як в Україні, так і в інших країнах світу, яке має динамічний характер $i$ тенденцію до зростання. Особливу увагу нині необхідно приділити деградації ясеневих насаджень, етиологія патології якої пов'язана із фрітопатогенною бактерією - Pseudomonas syringae pv. savastanoi. Загальна схема досліджень туберкульозної патології Fraxinus excelsior передбачала такі етапи: рекогносцирувальні та детальні лісопатологічні обстеження за загальноприйнятими лісівничо-таксаційними та фрітопатологічними методами; відбір уражених органів і тканин; ізоляція міко- і мікроорганізмів у чисту культуру; перевірка патогенних властивостей виділених ізолятів та їх ідентифрікація; дослідження антагоністичних взаємовідносин у системі «бактерія-бактерія», "бактерія-мікроміцет» як можливих чинників індукції демутаційних процесів у лісовий біоценоз. Збудник туберкульозу веде до формування типових туберкульозних виразок на вегетативних та генеративних оранах ясена звичайного. Характер патогенезу захворювання - хронічний, вагомо впливає на онтогенез рослини, зокрема веде до формування поліморфнних типів вад деревини та деформації насіння у дерев стиглого віку. Дерева молодого віку гинуть унаслідок спільної інфекції з іншими інфекційними агентами. Дерева порослевого походження відмирають у перші роки після зараження. Дослідження механізму системних взаємин (зокрема, антагоністичних) складових міко- $i$ мікробіоти туберкульозної патології ясена звичайного дає можливість втрутитися у процес регуляції патогенності й агресивності вітальних облігатов, иляхом застосування біопрепаратів для профрілактики і захисту деревних насаджень від збудників бактеріозів. На різних стадіях туберкульозної патології Fraxinus excelsior L. ізольовані Erwinia horticola, Pseudomonas sp., P. fluorescens, P. syringae, P. agglomerans, Xanthomonas sp., спороносні бактерії Bacillius sp., а також мікроміцети Acremonium strictum, Cladosporium cladosporiodes, Cylindrocarpon didymum, Fusarium sp., F. sporotrichiella, F. heterosporum, Phoma sp., Ulocladium botrytis тощо, які використані в дослідженнях як «антипод» збудника туберкульозу. Встановлено, що бактерії роду Bacillus sp. здатні пригнічувати адгезію і виживання фimопатогенних P. syringae pv. savastanoi на поверхнях і в тканинах тест-рослин, елімінуючи популяцію патогена або зменшуючи ї̈ щільність з імовірною атенуцією властивостей, механізм якої потребує подальших досліджень.
\end{abstract}

Ключові слова: бактерії, гриби, ясен звичайний, антагонізм, Pseudomonas syringae pv. savastanoi.

Отримано: 2021-03-19 